\title{
抜歯創の初期治瘾過程における血管内皮細胞の電顕的研究
}

\author{
岡田裕之・釜㠃直人・追川哲雄 \\ 泉 廣次・小澤幸重*
}

\section{Electron microscopical study of endothelial cells on early healing process in tooth extraction wounds}

\author{
Hiroyuki Okada $\cdot$ Naoto Kamasaki - Tetsuo Oikawa \\ Hirotsugu Izumi - Yukishige KozawA*
}

\begin{abstract}
The vascularization is an important factor along with the wound healing process, and there are some reports on extraction wounds. However, the ultrastructure of newly developed capillaries in the healing process is still argued. It is aimed of clearing the ultrastructural early healing process of endothelial cells in the experimental tooth extraction wound by electron microscopy.

Immediately after the extraction, the diffused basal lamina intermittently surrounded endothelial cells. Three days after the extraction, the basal lamina was not continuous, but had no gap with endothelial cells. Four days after the extraction, the basal lamina almost reconstructed.

On tannic acid injection into blood vessels, it was observed in the narrow lumen of cell masses which continued to capillaries. It is suggested that cell masses are derived from the endothelial cells, and are the precursor of capillaries.

The cell masses were formed by two or three undifferentiated endothelial cells. The narrow lumen was observed in the cell mass and these cells project short folds into the lumen. These cells connected by tight junctions, but the basal lamina was not complete. On tannic acid injection, it does not perfuse into the stroma through the basal lamina. It is concluded that these types of connections between the endothelial cells, were one of the characteristic features of capillaries in the tooth extraction wound.
\end{abstract}

Key words: extraction wounds (拔菌創), endothelial cells (内皮細胞), ultrastructure（微細 構造)

緒言

抜歯創の治癒・修復に関する研究は，動物実験を用い た開放性抜歯創について基本的な経過が 報告されてい
る 十分に解明されていない2,5 9).

創傷治癒に扣いて重要と考兄られる血管内皮細胞は, 血流といら機械的ストレスを受け，また，血液と組織・ 細胞との物質交換・分泌の機能とともに，高い分化的多
日本大学松戸歯学部第 1 口腔外科学教室

（主任：泉 廣次教授）

* 日本大学松戸歯学部第 2 解剖学教室

（主任：小澤幸重教授）

Department of Oral Surgery, Nihon University School of Dentistry at Matsudo (Chief: Prof.
Hirotsugu Izumi)

* Department of Anatomy, Nihon University School of Dentistry at Matsudo (Chief: Prof. Yukishige Kozawa)

受付日：平成 3 年11月 21 日 


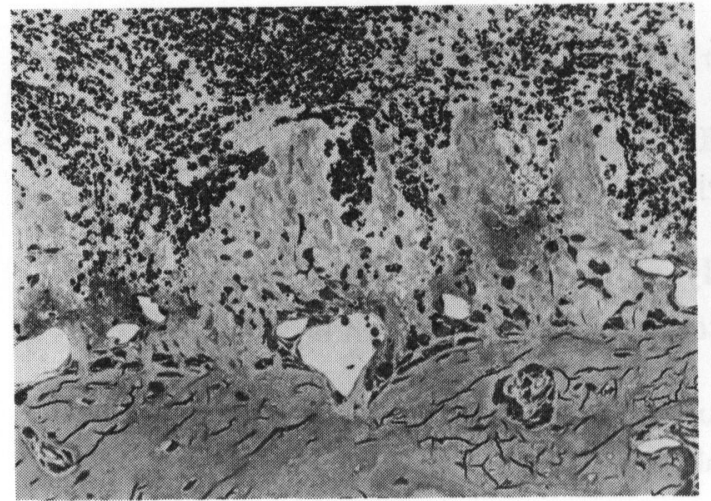

Fig. 1 The remained periodontal ligament is recognized between the bone and blood cells. Capillaries are observed near the bone surface of alveolar fossa in the remained periodontal ligament. $\times 600$ (Immediately after the extraction)

能性があるといわれる ${ }^{10,11)}$ 。一方では，血管の新生に は, 内皮細胞を囲む基底膜が重要な働さをなすといわれ ている ${ }^{12,13)}$ 。それゆ光, 内皮細胞は多様な機能的特性を 反映した形態をとり，その微細構造も血管の種類や部 位, 器官によって著しく器官特異性があることがあきら かとなりつつある ${ }^{14,15)}$. 血管は種々の刺激を受けて作用 する歯根膜中に豊富に存在し, これを養らためさまざま な機能を有すると考兄られる。しかし, 歯根膜の内皮細 胞に関して形態学的に微細構造を扱った研究は少な く ${ }^{16 \sim 18)}$, 基本的な姿も十分にあきらかになっているとは い党ない。

そこで本研究は, 抜歯創の治瘾過程に打ける血管内皮 細胞を, 電子顕微鏡を用いて 微細構造的に 検討を加兄 た。

\section{材料と方法}

実験として，5週龄（体重約 $100 \mathrm{~g}$ ）のウイスター系 雄性ラット（日本クレア社）32匹を用いた。飼料はオリ エンタル MF（オリエンタル酵母社）を与光, 水道水と ともに自由摂取させた、ペントバルビタールナトリウム （ネンブタール $1 \mathrm{ml} / \mathrm{kg}$ ダイナボット社）腹腔内麻酔下, 手術野を $3 \%$ 過酸化水素水捛よび $0.025 \%$ 塩化ベンザル コニウムにて消毒の後, 歯周組織にできるだけ障害を与 党ぬよう飞探針，スプーンエキスカペーターおよび乳歯 用下顎残根針子を用いて上䋶左側第 1 日歯を拔去した。 拔歯創は開放創とし，自然治痖にゆだねた。

\section{1. 観察期間}

抜歯直後と抜歯後 $1 ， 2 ， 3 ， 4 ， 5$ 打よび 7 日目の組織 像を観察した。

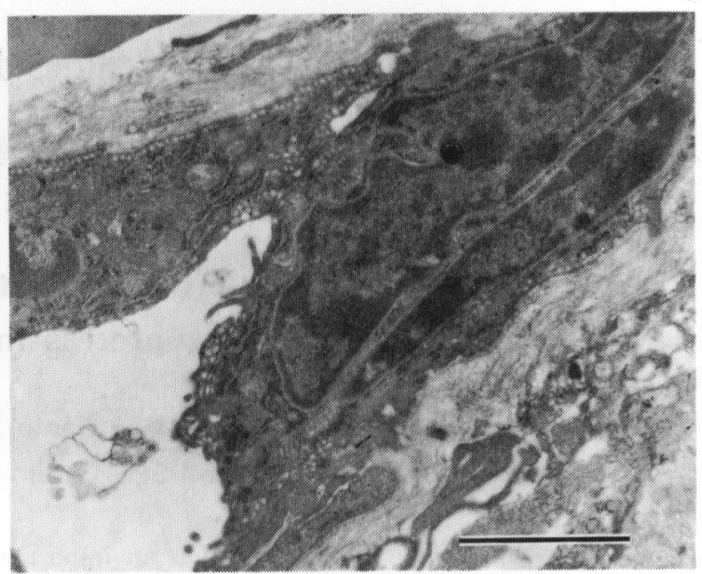

Fig. 2 The diffused basal lamina is partly observed around the capillary. Connective tissues disordered. However, many vesicles are observed in the cytoplasm of the endothelial cell, same as normal cells. The arrangement and distribution of organellae are more irregular than the normal one. The cell junctions of endothelial cells make loosely. Bar $=2 \mu \mathrm{m}$ (Immediately after the extraction)

\section{2. 標本作製および観察部位}

ペントバルビタールナトリウム腹腔内麻酔下で, 左心 室に留置針を插入し， ヘパンン添加生理食塩水 $(10 \mathrm{U} /$ $\mathrm{m} l)$ にて十分に駆血洗浄を行った後, $2.5 \%$ グルタール・ アルデヘイド溶液 (0.1M カコジレート緩衝液 $\mathrm{pH}$. 7 . 4) にて灌流固定を行った。試料採取後, 2 日間同固定液に 浸漬させ， $10 \%$ EDTA 溶液にて $4^{\circ} \mathrm{C}$ で 14 日間脱灰を 行い, 前頭断方向に分割し， $2 \%$ 四酸化オスミウムで後 固定挌よびエポキン樹脂包埋した。

タンニン酸注入標本は, 同固定液に $0.4 \%$ タンニン酸 を加光, 同様に固定, 包埋した.

包埋試料を薄切 $(1 \mu \mathrm{m})$ し，トルイジンブルー染色を 施し光学顕微鏡で観察し, オリエンテーションを得た。 抜歯直後は残存歯根膜, 抜歯後 $2 \sim 4$ 日目は血管新生が 盛んと考兄られる血餅周囲の肉芽組織, 抜歯後 5 扣よび 7 日目は抜歯窩中央部を残してトリミングを行った。 そ の後, これを超薄切片とし, 酢酸ウラン・クエン酸鉛の 二重染色を施して透過型電子顕微鏡（日立 HS-9）にて 観察した.

結

果

\section{1. 抜歯直後}

抜歯窝は赤血球を主体とする血球成分で満たされ，歯 槽骨の一部に歯根膜が残存していた。一部に残存する歯 


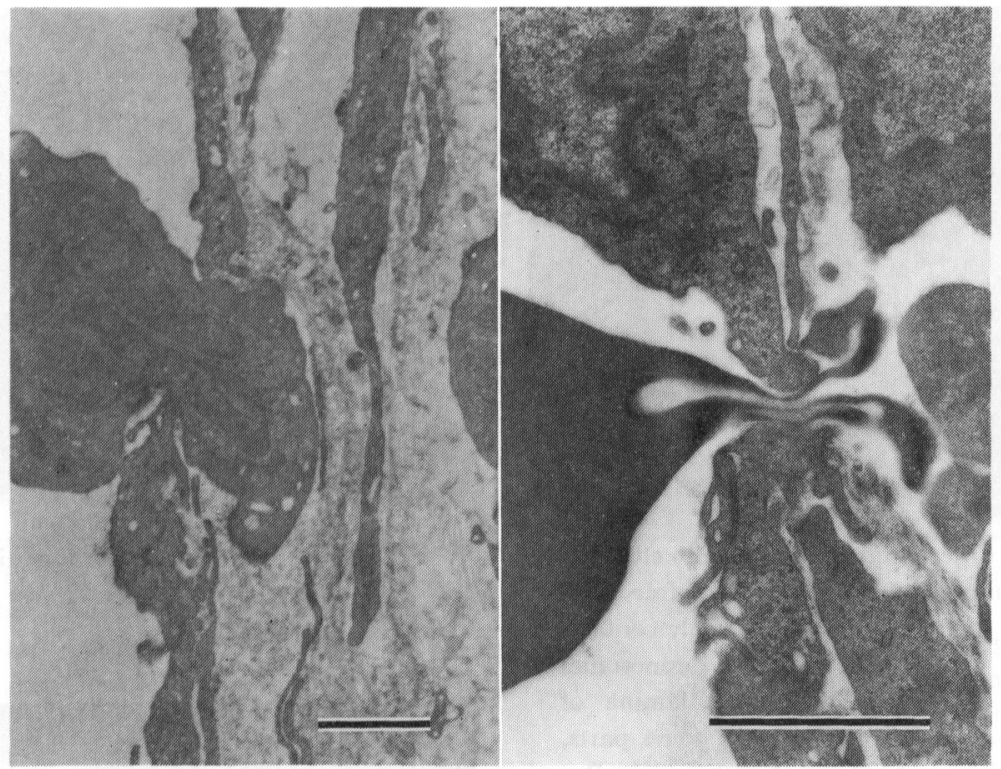

Fig. 3 A leukocyte is passing through the capillary, which is damaged one. The capillary, containing the leukocyte in the lumen, contains vesicles and other organellae. The junction of endothelial cells are separated together. The basal lamina, which becomes diffuse and separates from endothelial cells, is partly observed. Bar $=2 \mu \mathrm{m}$ (One day after the extraction)

根膜中にのみ，既存の血管が認められた（図1）.

残存歯根膜中の毛細血管の大部分は連続性のものであ った. 出血部の近くには断裂された毛細血管が認めら れ，断裂部付近には血小板やリンパ球が毛細血管腔に凝 集する像が認められた。 内皮細胞は全体的に萎縮した形 態を示していた（図2）.

内皮細胞の核領域の細胞質には, 遊離リボゾーム, 粗 面小胞体 (以下 RER), ミトコンドリアなどか゚観察され た。 小胞は多数認められ，その分布は管腔側では不規則 に散在するが，基底側の細胞膜の近くでは正常歯根膜の 毛細血管と同様に一列に配列していた（図 2).

核領域以外の薄い細胞質の部位では, 微細線維の配列 やミトコンドリアの分布に規則性が認められるが, 小胞 は管腔側で分布が乱れ，基底側では規則的に配列してい た。細胞の境界，細胞と基底膜の間は開大していた。

内皮細胞の管腔への突起の形態は, 単純なものや樹枝 状のものなどさまざまであり, 赤血球が接着している像 も認められた。

血管の断裂部には基底膜が認められず, 周囲の基底膜 は断裂し, 部分的にしか認められなかった（図 2).

\section{2. 抜歯後 1 日目}

抜歯窩中央には血餅が存在して抢り，その周井を線維 が取り囲んでいた。歯槽骨に近い部分に肉芽組織が認め られ，少数の血管が観察された.
抜歯創の血餅の周囲に線維素と破壞されたコラーゲン を認め, 空胞変性のある細胞が多数観察された。毛細血 管は有空のものが少なく, 全体的に細胞間隙が開大して 扣り, 種々の形態変化が起こっている無空性のものを多 数認めた (図了).

核領域の細胞質は，正常毛細血管と比ぺて著しく乏し く, 若干のゴルジ装置, 遊離リボゾーム, ミトコンドリ ア, RER などが存在していた。核領域以外では, 少数 の遊離リボゾーム, 小胞, 微小線維などが散在するが, 正常に比べて細胞小器官が少なかった.

内皮細胞より伸長する突起は,さむざまな形態をなし ていた。すなわち，管腔側の突起の基部に大きな陥凹を 形成したり，突起が管腔へあるいは血管外へ著しく伸長 することがあった，管腔への突起には，白血球と接する もの，またリンパ球を完全に包む形態が認められた。細 胞間隙は開大するが, 薄い内皮細胞の間隙から白血球や 赤血球が管腔外へ移動しつつある像が多く認められた (図了)。細胞間隙が開大した部では, 基底膜が断裂し, 分散していた。

\section{3. 抜歯後 2 日目}

抜歯窩中央の血餅周囲を, 線維素が網目状構造を形成 していた，肉芽組織の分布は抜歯窩全体にわたるが，毛 細血管は血餅周囲にはほとんど認められなかった。

抜歯創の凝血部の外側に, 毛細血管, 線維素, 赤血球 


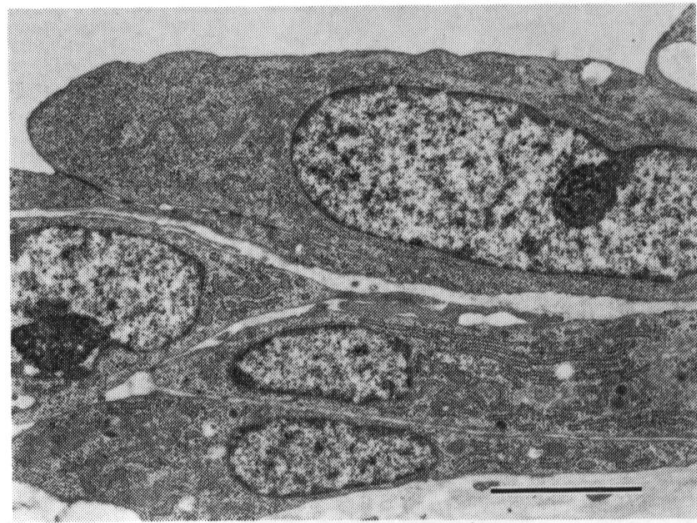

Fig. 4 Newly differentiated endothelial cells contain mitcchondria, RER and free ribosomes. These cells are smoothly contacted by newly differentiated desmosomes at cell junctions. The basal lamina of new endothelial cell lacks in some parts, and other parts it can be observed. Bar $=3 \mu \mathrm{m}$ (Two days after the extraction)

およよびュラーゲン線維が散在していた，有空性の毛細血 管はほとんど認められなかった，管腔内への突起は太い ものも多く認められ，伸長し管腔壁に大きな陷凹を形成 しているものも観察された.

血餅近くの毛細血管の内皮細胞は，核小体が明膫であ り，細胞内合成の機能が盛んであることを示していた (図 4). 核領域近くの細胞質は, 遊離リボゾームが著し く多く，ポリゾーム状をなしているものもあり，それに 囲まれて RER やミトコンドリアが密に配列していた。 その他に, 微細線維や微小管が散在して認められるよう になったが，小胞はあまり認められなかった，細胞質が 少ない領域では, ミトコンドリア, 遊離リボゾームが散 在し, 微細線維や微小管が走行していた. 内皮細胞間は tight junction や発達の悪い desmosome により接合し ていた。基底膜は非常に薄く, 部分的に認められるのみ であった（図 4).

一方, このような細胞の一部は, 結合組織中に伸長す るが，その細胞質中には，遊離リボゾーム， RER，ミ卜 コンドリアが少数認められ, 微細線維と微小管が密に繸 走していた。管腔外へ伸長している部分の基底膜は非常 に薄く，部分的に認められるのみであった。

血管にタンニン酸注入を行らと, 肉芽組織が分化した と考えられてきた細胞塊のわずかな細胞間陌にタンニン 酸を認めた. 細胞塊を構成する細胞は, 細胞質が多く, RERが発達し，遊離リボゾームが密集していた。 また， 部分的に微細管と微細線維が走行していた。 基底膜は不 完全に細胞塊を囲んでいるが，汇とんど認められない場 合もあった。多くの細胞塊は 2,3 個の細胞集合であり,

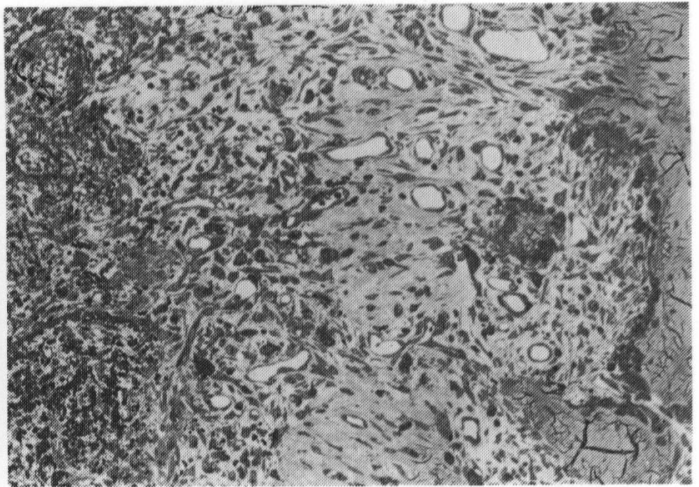

Fig. 5 Many capillaries and cell masses are recognized in granulation tissue near the blood clot. $\times 400$ (Three days after the extraction)

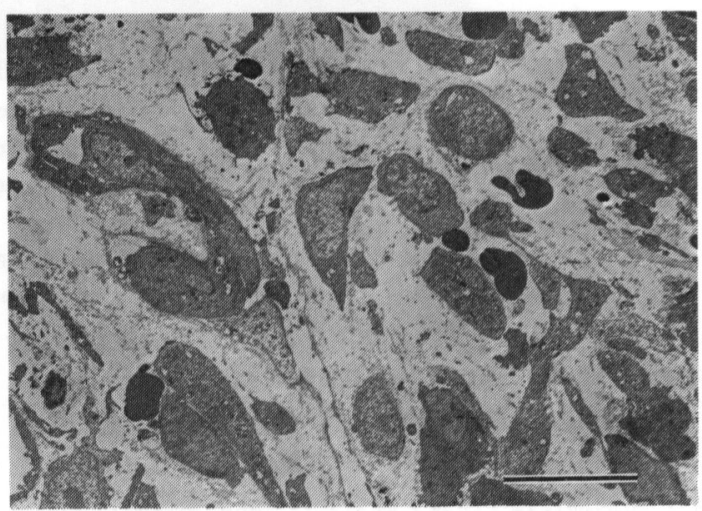

Fig. 6 Cell masses and some degenerated capillaries are observed in granulation tissues near the blood clot. Bar $=10 \mu \mathrm{m}$ (Three days after the extraction)

わずかな細胞間隙を有し, 相互に tight junction や発達 の亜い desmosome で接合していた.

\section{4. 抜歯後 3 日目}

抜歯窩中央部の血餅は縮小し，血餅周囲には厚い肉芽 組織が存在し，抜歯窩を満たしていた。肉芽組織の中， 特に歯槽骨周辺に多数の血管が認められるが, 血餅周囲 にも毛細血管や細胞塊が観察された（図 5).

抜歯創の血餅の周囲には毛細血管, 赤血球, コラーゲ ン線維, 線維芽細胞扣よび線維細胞を認め, 2 日後に比 ベて細胞塊ないし毛細血管が多数認められるようになっ た (図6).

血餅に近い部位の血管のほとんどは無空性の毛細血管 であり, 歯慒骨に近づくにつれて筋性の血管が認められ た. 無空性の毛細血管は, 立方形の内皮細胞 2,3 個で 構成されるもの, やや丈の低い立方～扁平の内皮細胞よ 


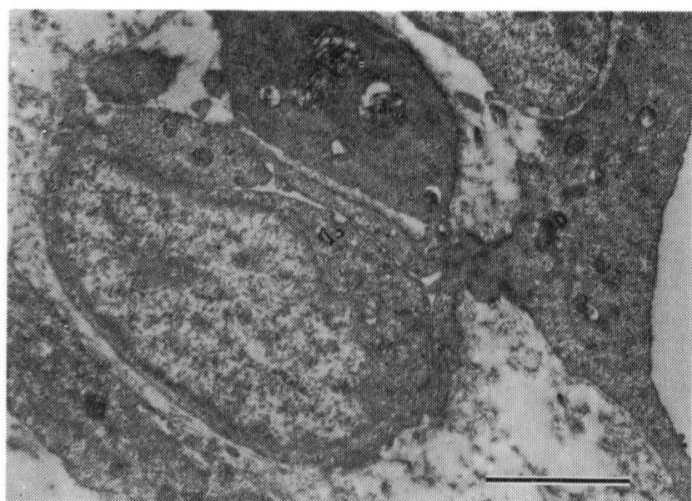

Fig. 7 The endothelial cell of newly developed capillary has a projection, penetrating into the stroma through basal lamina, and folds other cell in it. These cells may have active function. The basal lamina reconstructs around endothelial cells. Bar $=2 \mu \mathrm{m}$ (Three days after the extraction)

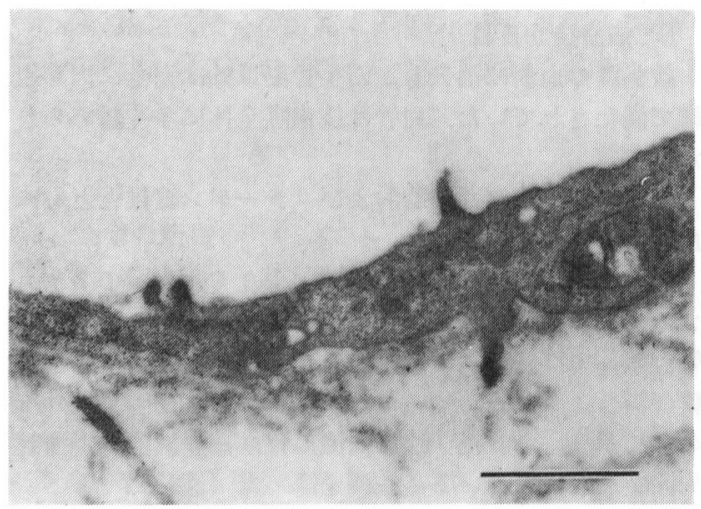

Fig. 8 The endothelial cell contains some RER, microfilaments, microtubules and so on. The basal lamina is not continuous, but has no gap with endothelial cells. Bar= $1 \mu \mathrm{m}$ (Three days after the extraction)

りなるもの，丈の高い内皮細胞よりなり，一部の血管壁 が薄くなっているものなども認められた。 内皮細胞は, 核が細胞質に対して大型であり,遊離リボゾームや RER なと゚を核領域に認め, ミトコンドリア，細線維や微小管 が多くなり，各種の小胞が細胞質中に認められた。ま た，管腔へ大小の突起を伸長させていた。一方，内皮細 胞の血管外への突起も多く，一部は基底膜を貫いて伸長 し，間質にある細胞を包み込む像も認めた（図 7). 基 底膜は連続的ではないが，内皮細胞とより密着し，厚み を増していた（図8）。

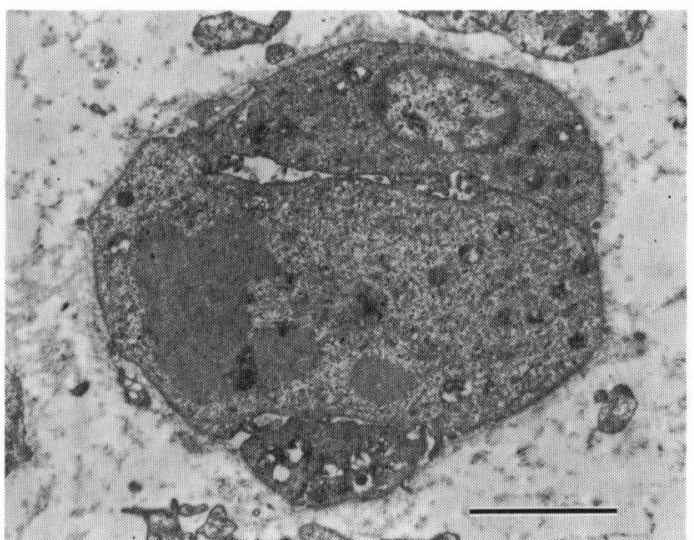

Fig. 9 A mitosis can be recognized in one of the cell masses, in which a small gap is observed, and some folds project into the lumen. These structures are similar that of undifferentiated capillary in the periodontal ligament. Amorphous structures circle around the cell mass. Bar $=2 \mu \mathrm{m}$ (Three days after the extraction)

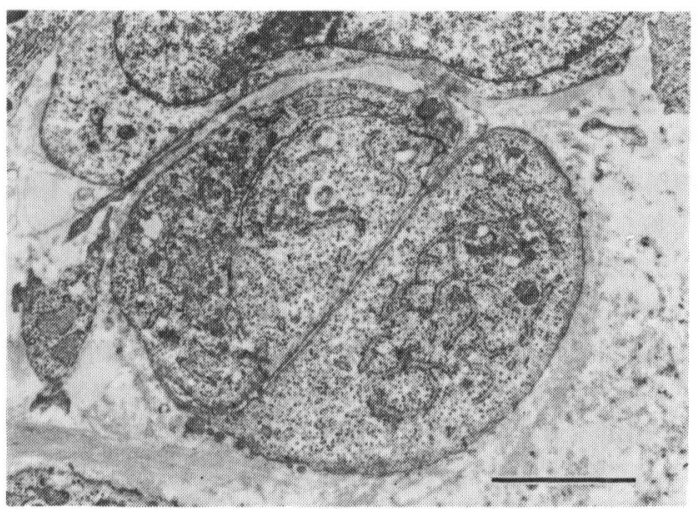

Fig. 10 On tannic acid injection, the tannic acid is recognized in the narrow lumen of the cell mass, which contains many RER and free ribosomes in the cytoplasm. The endothelial cell contacts to a mesenchymal cell with a projection. Bar $=3 \mu \mathrm{m}$ (Three days after the extraction)

細胞塊は 2,3 個の tight junction や desmosome 結 合によって接合しているが, 細胞間隙に小腔があり, 周 囲の細胞から突起を出していた（図9). しかし, 辺縁 ヒダは認められなかった。塊形成する細胞には核分裂像 が多く認められた（図9）。細胞には遊離りボゾーム， わずかな RER, 円形のミトコンドリア拉よび豊富な微 細線維を有して特り，わずかな細胞間隙に沿う細胞質に 


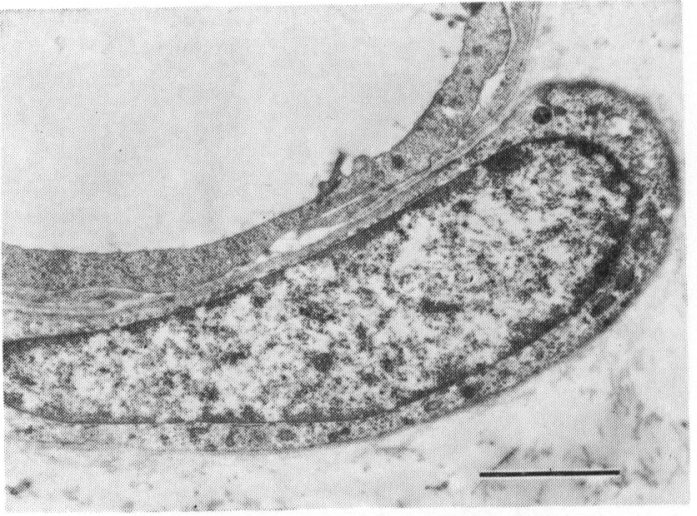

Fig. 11 The basal lamina almost continuously surrounds endothelial cells and pericyte. Free ribosomes, microtubules and tonofilaments are observed in endothelial cells. Stress fiber runs in the cytoplasm near cell membrane of pericyte. Bar= $2 \mu \mathrm{m}$ (Four days after the extraction)
は小胞らしきものも認められた。また, 細胞周囲にも突 起を伸長させ, 肉芽組織の細胞と接着するものも多数認 められた（図10）。細胞周囲には依然として, 未発達の 基底膜構造が取り团んでいた，血管ヘタンニン酸を注入 すると, 細胞塊の間隙にはタンニン酸が認められ, 細胞 塊が毛細血管と連続して拉り, 内皮細胞が伸長したもの であることが 2 日目同様に立証された（図10）。

\section{5. 抜歯後 4 日目}

抜歯窩の血餅にほぼ認められなくなり，拔歯窩上部に も多数の毛細血管が認められた。少数の新生骨梁も観察 された。

抜歯創全体に毛細血管, コラーゲン線維, 線維芽細胞 打よび線維細胞を認めた。歯槽骨近くには 2,3 層の平 滑筋が囲む筋性の血管が多く認められた。

毛細血管の多くは無空性であった。細胞質は遊離りボ ゾームに富み，RER やミトコンドリアをわずかに含み, 細胞膜近くには多数の小胞が認められた。 その周囲を周 皮細胞が覆い, 周皮細胞にも小胞が認められた。 また, 微細線維束が多数認められ, 基底側の細胞膜および周皮 細胞の内皮細胞側の細胞膜直下の近くには stress fiber も認められた。基底膜は, ほぼ連続的に血管周囲を取り 囲んでいた（図11）.

立方形の内皮細胞を伴う部位では, 細胞間の結合が良 く発達していた。基底膜は均一飞発達し, 細胞質中には 微細線維や微小管が豊富に認められ, Weibel-Palade 小 体もわずかではあるが認められた。

筋性の血管では, 内皮細胞の 周囲飞 2,3 層の平滑筋 が取り囲んでいた。内皮細胞と平滑筋は一部で互いに突 起を出して結合し, 両者に stress fiber が影著に認めら

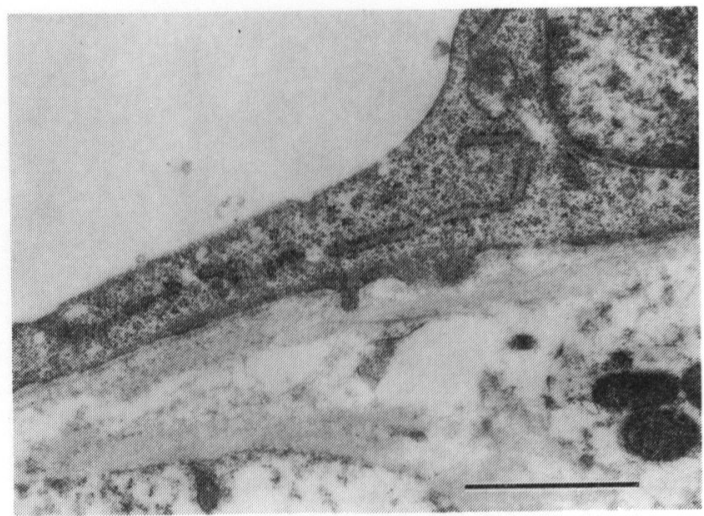

Fig. 12 The basal lamina almost continuously encircles the endothelial cell, which contains RER, vesicles, microfilaments and many free ribosomes. Stress fiber is recognized in the cytoplasm near cell membrane. Bar $=1 \mu \mathrm{m}$ (Five days after the extraction)

れた。

\section{6. 抜歯後 5 日目}

抜歯窩の血餅は消失し, 新生骨梁以外は完全に肉芽組 織で満たされていた。血管は拔歯窩全体に多く認められ た.

線維細胞，線維芽細胞およびュラーゲン線維とともに 血管が認められた.

毛細血管の内皮細胞の細胞質は少なく，少数のミトコ ンドリア，RER，特よび遊離リボゾームが認められた。 管腔側怙よび基底側の細胞膜には小胞, 基底側には細胞 膜に沿ら上うと走行する stress fiber 拈よび管腔内外一 の突起が認められた，血管周囲にはほぼ連続的に，血管 周囲を取り囲んでいる基底膜を認めた（図12）。

\section{7. 抜歯後 7 日目}

拔歯窩は，注ぼ新生骨梁で満たされていた。新生骨梁 に囲まれた線維性組織中には, 骨梁に沿うょうに血管が 分布していた。

新生された歯槽骨に囲まれた結合組織中に観察される 径の小さな血管は以下のと衫りであった。

全体的㳄皮細胞の細胞質は豊かになり, ミトコンド リア，遊離リボゾーム括よび微細線維が多数認められ た。 小胞は細胞質全体飞散在して打り, 管腔側の細胞膜 飞沿って配列している部分もあった。管腔特よび管腔外 への突起は単純であり, 少数が認められるのみであっ た。突起の細胞質には小胞, 微細線維が観察されること もあった。 内皮細胞間は tight junction 招よび desmosome で接合して括り，接合部には辺縁ヒダが認められ た，血管周囲には周皮細胞とともに，平滑竻が認められ た，基底膜は，ほぼ連続的に血管を取り因んでいた（図 


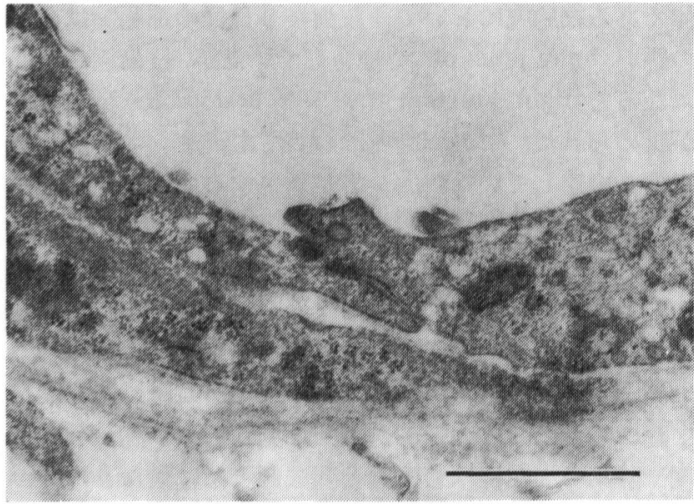

Fig. 13 The endothelial cells contains vesicles, microtubules and many microfilaments. These cells connect by tight junctions. The basal lamina almost continuously surrounds endothelial cells and pericyte. Bar $=1 \mu \mathrm{m}$ (Seven days after the extraction)

13).

な拝, 抜歯直後〜抜歯後 4 日後の血管内皮細胞の微細 構造の変化，扣よび血管新生について図14に示す.

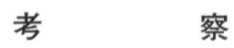

\section{1. 血管の新生}

創傷治癒における血管新生に関しては, 肉芽組織中に 形成される細胞塊が内皮細胞化し血管形成する局所発生 説 $^{19,20)}$, 血管の内皮細胞が分裂して伸長する芽生説 ${ }^{21 ~ 23)}$ などが考えられている。

本実験では光顕的に抜崡後 2 日目以後, 細胞塊と内皮 細胞の両者に核分裂が認められた。ささらに抜歯後 2 日目 以後は, 内皮細胞自身が基底膜を貫き間質へ成長する像 が多数観察され, その断面は数個の細胞の塊として観察 された. 光瞟的に肉芽組織中に細胞塊が多数認められる のは, 抜歯後 $2 \sim 4$ 日目, 特に 3 日目で明瞭であった. このような毛細血管とは無関係のように観察される細胞 塊が，今回用いたタンニン酸注入法によれば, 細胞塊の わずかな細胞間腺にもタンニン酸が認められ, 細胞塊は 毛細血管と連続し，新生してきたものであることがあき

\section{らかである。}

すなわち, 抜霜創に拈いては細胞塊が既存の血管内皮 細胞由来であり，図14に示したごとく，抜歯により血管 が破断され，抜歯後 1 日目には血管断端が狭くなり，2 日目になると血管断端が間質へ伸長し，3 日目に断端の 内皮細胞が分裂しつつ伸長し，管腔形成して新しい血管 が形成されると考劣る。

毛細血管の核分裂が血餅近くや細胞塊に 認められた

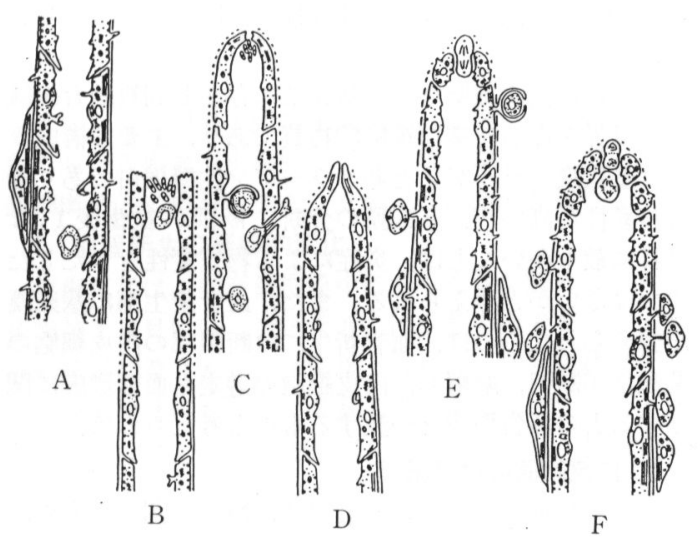

Fig. 14 Scheme of angiogenesis of extraction wounds.
A: Normal
B: Immediately after the extraction
C: One day after the extraction
D: Two days after the extraction
E: Three days after the extraction
F: Four days after the extraction

が，斉木 ${ }^{20)}$ の指摘したごとく先端よりやや手前で核分裂 牤よび細胞分裂が行われるのではなく, 先端に扣いて行 われると考劣わる。

タンニン酸の注入法は, 他の組織の血管の研究にも多 く用いられており，内皮細胞から基底膜を貫いて血管外 へ拡散する現象も示されている15)。乙かし，抜歯創に拉 いては脳の血管同様に血管外への漏出は認められない. この点は抜歯創の毛細血管を形成する内皮細胞の特長と 考觉られる。

\section{2. 基底膜}

電影的には，抜歯直後から抜歯後 2 日目では基底膜が 分断されたままであり，内皮細胞との間に著しい間隙が あった，抜歯後 3 日目以後になると, 電子密度の高い層 が厚くなり，部分的に内皮細胞へ接着していた，抜歯後 3 日目以後でも, 新生する付近の細胞塊の基底膜は欠如 するかまたは断裂していた。

抜歯後 $2 \sim 4$ 日目の内皮細胞の一部が，新生毛細血管 形成のために基底膜を貫いて伸長する像が多数認められ たが，伸長する内皮細胞の先端には基底膜は認められな い.内腔がほとんど未完成の細胞塊の周囲にも汪とんど 基底膜が認められない。一方では，内皮細胞から間質へ 伸びて周囲の細胞と 接着する突起も基底膜を欠いてい た.

すなわち，基底膜は図14に示したごとく，血管の断裂 部では認められず，その周囲のものも断裂しているが, 血管の再生とともに基底膜は形成され, 電顕的な基底膜 が完全に形成されるのは，血管や毛細血管の微細構造抒 
よび機能が回復した抜歯後 4 日目以後になると考えられ る.

基底膜は内皮細胞などの基底部に存在し間質結合組織 との境界を作る特殊な細胞間物質であり, 主要な構成成 分は基底膜コラーゲンと非コラーゲン性糖蛋白であり器 官特異性が高い24). 基底膜の分断，断裂が抜歯後 1,2 日目に最も多いことは，炎症による物質変性をさたした のではないかと考えられる，また，血管新生部に基底膜 が認められないのは, 血管新生には断裂部の内皮細胞の 基底部が断裂, 融解し, 内皮細胞の遊走と血管形成に関 与するとの報告 ${ }^{12,13)}$ と一致するものと考学られる.

\section{3. 内皮細胞の微細構造}

血管の微細構造に関する研究は, 輸送に関するものが 多い25 27). 歯根膜の血管の微細構造を研究したものは, 有空性毛細血管の比率などの窓に関してのもの ${ }^{18)}$, 径の 大きさなどを計測的に分析しているもの吾などである. まず，一般的な形態としては，歯根膜には有空性毛細血 管が存在し ${ }^{16)}$ ，ラットの歯根膜の毛細血管にもとづく少 数の空を有する ${ }^{18)}$ といわれている. しかし，その形態は 機能に応じて変化すると考兄られ, 必ずしも固定したも のではなく ${ }^{28,29)}$, 拔歯創に打ける血管新生の微細形態学 的な検討はほとんどない.

実験対照群の正常歯根膜の毛細血管は，大部分は連続 性のものであったが，一部に径 $80 \mathrm{~nm}$ ほどの空を認め た.これは歯根膜が，腎蔵や内分泌腺のように盛んな物 質交換 ${ }^{15)}$ を行ら部位と異なるためではないかと考えられ る. 抜歯後も連続性毛細血管が多く, 新生血管の前駆体 である細胞塊から形成される新生血管は，すべてが連続 性毛細血管であった。

内皮細胞の辺縁部の接合部は互いに接着しており, 主 に, tight junction と gap junction からなる30) といわ れる. 正常歯根膜に执いて, 内皮細胞間は tight junction またはごく一部に desmosome 様の構造が観察された. 内皮細胞間の tight junction による閉鎖状態は，器官や 部位により発達に差がある ${ }^{31,32)}$. 抜歯創に特けるタンニ ン酸注入によって，細胞間接合部までタンニン酸を認め るが，基底膜には達していなかった。 これは歯根膜の毛 細血管の細胞間結合は脳の毛細血管 ${ }^{15,17)}$ 同様に強くシー ルされているものと考えられ，雪根膜の特徵であろうと 推定される.

抜歯直後扣よび抜歯後 1 日目では, 細胞境界は開大し ているが，炎症時や高血圧状態に tight junction が離開 するとの報告 ${ }^{33)}$ があり，今回の結果とほぼ同様と考えら れる，抜歯後 2 日目になると細胞間は tight junction や 発達の悪い desmosome 様構造により接合するようにな ったが，タンニン酸の管腔外への浸出は認められず，固 い内皮細胞間の結合は回復しているものと考えられる. 抜歯後 3 日目以後は実験対照群と比べ変化はなかった.

一方，抜歯後 $2 \sim 4$ 日目に認められる新生血管の前駆
体である細胞塊に执いて, 抜歯後 2 日目の細胞間は発達 の悪い tight junctior で接合していたが, 抜歯後 3 日目 になると tight junction や若干の desmosome 様の構造 が認められた。この細胞塊に拈いても，タンニン酸は基 底膜まで達していない。つまり新生する血管の細胞間は 強く接合し管腔が形成されると考えられる.

連続性の毛細血管は，物質代謝の盛んな組織で小胞な いし小窩の発達が良い25)。内皮細胞は，管腔側と基底側 いずれの形質膜直下に直径約 $60 \sim 70 \mathrm{~nm}$ の小胞ないし 小窩といわれる構造が集積し，多くは形質膜に開口した 小窩 ${ }^{15)}$ であるとの報告がある，小胞ないし小窩の分布密 度や酵素の局在性は管腔側と基底側とでは異なり, stress fiber による収縮作用や物質透過性の制御，血小板の付 着, 物質輪送などの機能が指摘されている ${ }^{34)}$. 小胞構造 は，すべての血管で一様に認められるものではなく，同 じ血管でも部位により数は異なり, 脳内毛細血管では極 めて小胞や小窩が少なく，筋組織内毛細血管では著しく 多(30)

今回の結果では, 抜歯直後には各種の小胞の配列や数 が著しく乱れ，主に基底側の細胞膜近くに比較的多数, 管腔側には少数観察された. 抜歯後 1 日目からは, 少量 の小胞が散在するのみで，この状態が抜歯後 2,3 日目 頃までつついた。抜歯後 4 日目になると細胞膜近くに多 数の小胞が認められるようになり, 一部では, 基底側の 細胞膜に規則的に配列する小胞も観察された。この時期 には内皮細胞の外側に集まる周皮細胞や平滑筋の前駆細 胞にも同様の構造が認められた. すなわら, 抜歯後 1 3 日目までは新生内皮細胞の輸送や筋の収縮機能が不完 全であり，それ以後になって回復されることを示してい るものとも考えられる。, 一方, 細胞塊に掞いては, 小胞 扣よび小窩は若干認められるに過ぎず, 輸送に関する機 能はまだ不完全なものとなっている.

内皮細胞の管腔および管腔外への突起に関する報告は あまりないが，突起は一般の上皮細胞の自由表面にみら れる微絨毛と同様に, 内腔の細胞の表面積を著しく増大 させ，血流に影響を与え，形質膜を通しての物質代謝お よび血小板の付着に関連するのではないかとの報告があ る ${ }^{14,35)}$. また一方では, 突起中に小窩が認められること から，白血球などの接着にも関与していることが指摘さ れている ${ }^{34)}$. 今回の結果でも, 赤血球や血小板, 白血球 と接着する突起が抜歯後 1,2 日目に認められ，抜歯後 2 日目では管腔内外に伸長し完全に細胞を包み込んでお り, 中に小冎状構造を有しているため, 突起が積極的に この機能を果たしていることが示された.

内皮細胞の辺縁部の接合部から伸長する辺縁ヒダに関 しては，ヒダが反転し基部に空胞を作り，空胞が基底側 に移動し内容物を放出する ${ }^{36)}$ との機能と関連するとも考 えられる，歯根膜の内皮細胞の突起の形はさまざまであ り, Fujimura ${ }^{17)}$ の報告のごとく機能の多様性を示して 
いるものと考えられる.

本実験の細胞塊においては，形成され始めた管腔に突 出する突起を認めたが, 非常に少ない.この結果は幼弱 内皮細胞には辺縁ヒダの構造は認められないが, 表面に 微䋐毛様突起が存在している ${ }^{35)}$ との報告と一致する.

一方, 基底膜を貫いて結合組織中に侵入する内皮細胞 の突起むあるが，抜歯後 2 日目以後になると結合組織細 胞との接触が多く認められ，一部は細胞を完全に包んで いた。 突起には小胞や小窝が多く, 細胞接着の機能を果 たしていると考兄られる。.さらに抜歯後 3 日目以後に拉 いては, 周囲の平滑筋細胞中へ内皮細胞が突起を伸長 し, tight junction を形成しているものが 観察された. 内皮細胞の前駆体と考兄られる細胞塊からも突起の伸長 が同様に認められた。これらの細胞塊や内皮細胞からの 間質への突起は, 結合組織の細胞と接し, 周皮細胞や筋 紐胞への誘導に関与する現象のひとつではないかと考兄 られる.

内皮細胞の細胞骨格を形成する線維性蛋白質は微細線 維, 中間径フィラメントおよび微小管である ${ }^{37)}$. 微細線 維は束をなし, 通常, 基底側の形質膜近くを細胞長軸と 平行に直線状に走る ${ }^{38}$. そして微細線維束は大動脈の内 皮細胞で発達が良く，細胞の長軸方向に配列する stress fiber を形成し，血流によるずり応力に対抗する線維構 造として重要であり, stress fiber は血流速度の高い部 分, 特に左心室, 大動脈弁, 大動脈の内皮細胞飞発達が 良( ${ }^{39)}$. 中間径フィラメントは内皮細胞にも存在し ${ }^{40)}$, 核などの細胞内小器官の細胞内に和ける立体的な位置関 係の保持, 細胞外形の維持や細胞分裂に関係している ${ }^{41)}$. 微小管はチュブリンからなり, 細胞長軸方向に配列し細 胞質全体に散在し, 細胞の非対称的な外形を形成, 維持 している。.また, 内皮細胞が遊走する場合は, 微細線維 によって細胞運動を起こし ${ }^{42}$, 細胞分裂時の紡鏵体の骨 格をなし, 染色体が移動する際に重要な役割を果たす。 対照の正常歯根膜の毛細血管の内皮細胞には多くの微細 線維が観察されるとともに, 基底側の細胞膜近く飞錯走 する微細線維束が認められたことは, 歯の機能に応じた 收縮や驰緩が行われるものと考兄られるが, 抜歯直後で は乱れて錯走する微細線維束が認められ，拔歯後 2,3 日目になると細胞質に乏しい部分および基底側の細胞質 に微紐線維束や微小管が認められるようになった。拔歯 後 4 日目になると, 基底膜近くに stress fiber が認めら れるようになった，以上より，拔歯後 2,3 日目に stress fiber の形成が行われ，拔歯後 4 日目には平滑筇細胞に も出現し，かつ小管および小窩が双方の相対する細胞膜 に沿って出現することから, 収縮運動が他の機能ととも に確立され，行われつつあることを示していると考兄ら れる。

\section{結}

語

ラットの上靧第 1 日歯を抜歯し, 拔䨑創の初期治癒過 程に和ける血管内皮細胞について電子顕徽鏡を用いて, 微細構造的に検討を加え, 次のような結論を得た。

\section{1. 血管新生の経時的変化}

抜歯直後は, 残存歯根膜中にのみ血管が認められた。 抜歯後 1 日目には, 歯槽骨近くに少数の血管を有する肉 芽組織が観察された。抜歯後 2 日目は, 肉芽組織の分布 は抜歯窩全体にわたり，多数の血管を含んでいたが，血 餅周囲にはほとんど血管が認められなかった。拔歯後 3 日目になると, 血餅周囲の肉芽組織中に多数の毛細血管 や細胞塊が観察され，血管新生が著明であった，抜歯後 4 日目は, 血餅はほぼ消失し, 抜歯窩全体に多くの毛細 血管が認められた。抜歯後 5 日目, 血餅は消失し, 新生 骨梁以外は多数の血管を含む肉芽組織で完全に満たされ ていた，拔歯後 7 日目には，抜歯窩はほほ注新生骨梁で満 たされ，骨梁に沿うように血管が分布していた。

\section{2. 基底膜の変化}

正常歯根膜中の毛細血管周囲には, 厚さ約 $50 \mathrm{~nm}$ の基 底膜が連続しているが, 抜歯により血管の断裂部には基 底膜は認められず，周囲の基底膜は断裂し，部分的にし か認められなかった。抜歯後 3 日目では, 基底膜は連続 的ではないが, 内皮細胞との隔たりはなくなり, 厚みを 増していた。拔歯後 4 日目になると比較的正常な基底膜 に分化していた。

\section{3. 細胞塊と血管新生}

タンニン酸の注入を行うと, 創傷治癒に括ける局所発 生説の根拠のひとつとなっている細胞塊において, 微小 な内腔にもタンニン酸が認められ, 既存血管との連続性 が確認された。つまり, 細胞塊が内皮細胞から由来し, 分化して，血管を形成する前駆体であることが示唆され た.

細胞塊は電顕的に，2，3個の未分化な内皮細胞から なり，微小な管腔に突起を出し, 細胞間は tight junction で接合していたが基底膜は不完全であった．タンニン酸 が基底膜より漏出していないことより, 既存血管はもち ろんのこと, 新生血管の内皮細胞間の結合が強いことが あきらかとなった。

本研究の一部は, 第 45 回 日本口腔科学会総会 (1991 年, 京都) に打いて発表した。

\section{引用 文 献}

1）藤田訓也：拔菌創の治瘾飞ついて。茵界展望 61: 857-865 1983.

2）飯塚 正：放射線照射ラットの拔蒋創治瘾過程 
に関する形態学的研究。歯基礎誌 26：745-785 1984.

3）織間正亘 : 拔歯創治癋機転の実験的, 臨床的研 究. 口科誌 21：94-130 1972.

4) 斉藤俊夫：拔歯創治瘱過程に及ぼす活性型ビタ ミン $\mathrm{D}_{3}$ ならびにタンパク同化ステロイドの影 響—Microradiogram, ${ }^{45} \mathrm{Ca}$ autoradiogram に よる観察. 歯学 69: 864-897 1982.

5）阿比留信：正常開放性抜菌創に打ける血管の新 生扣よび変遷に関する実験的研究。久留米医会 誌 30：801-826 1967.

6）真木亮二：拔歯創の血管新生に関する実験的研 究. 岡山医会誌 72: 153-174 1960.

7）野間康弘：拔齿創の血管新生およびその経過に 関する実験的研究. 歯科学報 66: 288-365 1966.

8）島田純治：抜歯創の骨性治瘺に扣ける血管構築 の変化について。歯基礎誌 31：19-34 1989.

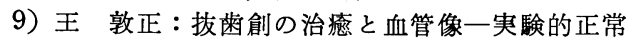
拔齿創の治癒。神奈川歯学 21：232-259 1986.

10）室田誠逸：培養血管内皮細胞の特性と機能分化. 代謝 25：877-884 1988 .

11）吉田洋二：血管内皮細胞の形態と機能。呼吸と 循環 37: 819-833 1989.

12) Form, D.M., Pratt, B.M., et al.: Endothelial cell proliferation during argiogenesis-in vitro modulation by basement membrane components. Lab Invest 55: 521-530 1986.

13) Furcht, L.T.: Critical factors controlling angiogenesis-Cell products, cell matrix, and growth factors. Lab Invest 55: 505-509 1986.

14）山田英智：血管内皮の構造と機能。血液と脈管 3: 511-521 1972.

15）山元寅男: 毛稩血管透過の形態学. 日臨 45(夏 季増刊号)：208-217 1987.

16) Corpron, R.E., Avery, J.K., et al.: Ultrastructure of capillaries in mouse periodontium. J Dent Res 55: 5511976.

17) Fujimura, A., Itoh, I., et al.: Morphometric analysis of the capillary loop endothelium underlying sulcular epithelium. Bull Tokyo Dent Coll 28: 23-33 1987.

18) Moxham, B.J., Shore, R.C., et al.: Fenestrated capillaries in the connective tissues of the periodontal ligament. Microvasc Res 30: 116-124 1985.

19）日下邦夫：創傷治瘾に関する組織学的研究一第 3 報, 肉芽組織に於ける血管 新生. 臨外科 6 : 171-173 1951.

20）斉木秀彦：実験的創傷治瘾における血管新生機 序. 久留米医会誌 41：185-206 1978.

21) Clark, E.R., and Clark, E.L.: Microscopic observations on the growth of blood capillaries in the living mammal. Am J Anat 64: 251-301 1939.

22) Mikata, H., Watanabe, S., et al.: Pericyte in granulation tirsue. Recent Advance in RES Res 15: 19-34 1975.

23) Torikata, C., Takeuchi, H., et al.: Studies on the biological background of the sprouting of the vessels-Its relations to the plasma exudation. Keio J Med 20: 161-168 1971.

24）暒川欽一郎：基底膜，暒川欽一郎著; 結合組織, 第 1 版, 金原出版, 東京, 1984, 367-392頁.

25）猪口哲夫, 村上正浩: 毛細血管の微細構造一特 に，血管透過性に関わる諸構造について，細胞 13: 429-436 1981.

26）小林 繁：毛細血管内皮層における物質の通路. 医学のあゆみ 75：469-474 1970.

27) 山元寅男, 奥田隆司: 血管透過性の超微形態学. 脈管学 21: 99-102 1981.

28) Palade, G.E.: Fine structure of blood capillaries. J Appl Physics 24: 14241953.

29) Palade, G.E., and Bruns, R.R.: Structural modulations of plasmalemmal vesicles. J Cell Biol 37: 633-649 1968.

30) Simionescu, M., Simionescu, N., et al.: Segmental differentiations of cell junctions in the vascular endothelium-Arteries and veins. J Cell Biol 68: 705-723 1976.

31) Karnovsky, M.J.: The ultrastructural basis of capillary permeability studied with peroxidase as a tracer. J Cell Biol 35: 213-236 1967.

32) Simionescu, M., Simionescu, N., et al.: Segmental differentiations of cell junctions in the vascular endothelium-The microvasculature. J Cell Biol 67: 863-885 1975.

33) Hüttner, I., Costabella, P.M., et al.: Volume, surface, and junctions of rat aortic endothelium during experimental hypertension-A morphometric and freeze fracture study. Lab Invest 46: 489-504 1982.

34）小川和重, 小川和朗：血管の酵素組織化学. 室 田誠逸編；血管細胞の培㽰とその応用，東京化 学同人, 東京, $1989,27-36$ 頁.

35）竹重順夫, 毛利 純, 他：血管新生機序に関す る電影的研究。脈管学 15: 271-275 1975.

36) Fawcett, D.W.: Surface specializations of absorbing cells. J Histochem Cytochem 13: 75911965.

37）石川春律: 細胞骨格の微細構造，蛋・核・酵 28: 624-635 1983.

38) Yohro, T. and Burnsteck, G.: Filament bundles and contractility of endothelial cells in coronary arteries. Z Zellforsch 138: 85-95 1973.

39) White, G.E., Gimbrone, M.A., et al.: Factors influencing the expression of stress fibers in vascular endothelial cells in situ. J Cell Biol 97: 416-424 1983.

40) Uehara, Y., Campbell, G.R., et al.: Cytoplasmic filaments in developing and adult 
vertebrate smooth muscle. J Cell Biol 50: 484-497 1971.

41) Savion, N., Vlodavsky, I., et al : Synthesis and distribution of cytoskeletal elements in endothelial cells as a function of cell growth and organization. J Cell Physiol 110: 129-
1411982.

42) Gotlieb, A.I., May, L.M., et al.: Distribution of microtubule organizing centers in migrating sheets of endothelial cells. J Cell Biol 91:5895941981. 